\title{
PENGARUH $e$-WOM TERHADAP BRAND IMAGE DAN PURCHASE INTENTION PADA HOTEL BINTANG TIGA DI BALI
}

\author{
Lourino Valentino Pentury ${ }^{1}$, Monica Sugianto ${ }^{2}$, Marcus Remiasa ${ }^{3}$ \\ ${ }_{1,2,3}$ Program Manajemen Perhotelan, Program Studi Manajemen, Fakultas Ekonomi, Universitas Kristen Petra \\ Jl. Siwalankerto 121-131, Surabaya, Indonesia \\ Email: Tiavalentino2510@gmail.com¹; monicalim.0573girl@gmail.com²; markus@petra.ac.id ${ }^{3}$
}

\begin{abstract}
Abstrak
Penelitian ini bertujuan untuk mengukur atau melihat pengaruh dari e-WOM dalam Online Review pada OTA terhadap brand image dan purchase intention pada hotel bintang tiga di Bali. Penulis melakukan survei dengan jumlah responden sebesar 213 responden dengan kriteria yang sudah ditetapkan menggunakan metode analisa SEM-PLS. Temuan menunjukan bahwa e-WOM berpengaruh secara positif dan signifikan terhadap brand image hotel bintang tiga di Bali. Brand image berpengaruh positif namun tidak signifikan terhadap Purchase intention hotel bintang tiga di Bali. Dan e-WOM berpengaruh positif dan signifikan terhadap Purchase intention hotel bintang tiga di Bali.
\end{abstract}

Kata kunci: Electronic Word of Mouth; Brand Image; Purchase Intention; Online Travel Agent.

\begin{abstract}
This study is intended to measure or to see the effect from e-WOM in an Online Review of OTAs on brand image and purchase intention in three-star hotels in Bali. The author conducted a survey with the number of respondents of 213 people with a specific criteria and use the method of SEM-PLS analysis. The findings show that e-WOM has positive and significant effect on the brand image of three-star hotels in Bali. Brand image has positive influential but not significant to the purchase intention of a three-star hotel in Bali. And e-WOM has positive and significant influence on the Purchase intention of three-star hotels in Bali.
\end{abstract}

Keywords: Electronic Word of Mouth; Brand Image; Purchase Intention; Online Travel Agent.

\section{PENDAHULUAN}

Persaingan semakin ketat dalam dunia bisnis di era globalisasi ini, tak terkecuali perhotelan, yang menyebabkan pelaku bisnis berupaya mencari cara untuk menarik perhatian konsumen. Mulai dari teknik pemasaran, peningkatan kualitas layanan sampai pada peningkatkan kualitas produk. Kotler \& Keller (2012) mengatakan bahwa pemasaran adalah aktivitas, sebuah lembaga, dan proses untuk menciptakan, mengkomunikasikan, dan bertukar penawaran yang memiliki nilai bagi pelanggan atau masyarakat luas. Pemasaran dapat dilakukan bukan hanya melalui face to face communication atau melalui media tv dan koran saja, tapi juga dapat dilakukan melalui media sosial.

Media sosial bukan hanya digunakan untuk melakukan promosi sebuah produk atau jasa dalam suatu bisnis, tetapi juga digunakan dalam pengambilan keputusan, misalnya untuk memilih sebuah hotel. Survei Online Travel Agency (OTA) telah dijalankan oleh DailySocial.id pada tahun 2018. Survei ini melibatkan sebanyak 2.013 responden pengguna smartphone di Indonesia. Hasil menunjukkan bahwa menggunakan OTA untuk kebutuhan travel (tiket pesawat, kereta dan reservasi hotel) sebanyak $71,44 \%$ responden dan mengakses OTA melalui aplikasi smartphone sebanyak 83,59\%. Sebanyak 96,69\% Responden setuju bahwa OTA telah membantu memudahkan dalam merencanakan dan mengeksekusi perjalanan, sebanyak 91,7\% responden setuju bahwa membeli tiket dan reservasi melalui OTA lebih ekonomis daripada agen perjalanan konvensional, dan sebanyak 95,18\% responden setuju bahwa tiket dan reservasi lebih mudah dibeli melalui OTA.

Data di atas menunjukan bahwa penggunaan dan preferensi masyarakat terhadap OTA sangat tinggi, terutama pembelian tiket dan reservasi hotel. Hal ini dapat tercermin dengan melihat pertumbuhan kunjungan wisatawan ke tempat-tempat wisata di Indonesia. Salah satu adalah pulau Bali sebagai tempat liburan paling populer di kepulauan Indonesia. Dan data yang didapat dari Badan Pusat Statistik (BPS) Provinsi Bali menunjukkan bahwa pada tahun 2015-2017 terjadi peningkatan jumlah wisatawan lokal yang berkunjung ke Bali, terutama tahun 2016 mengawali pertumbuhan $20,94 \%$, dan tahun 2017 meningkat lagi sebesar $1,06 \%$, seperti terlihat pada table 1 . 
Tabel 1. Kunjungan Wisatawan Domestik ke Bali per Bulan 2015 - 2017

\begin{tabular}{lrrr}
\hline \multicolumn{1}{c}{ Bulan } & \multicolumn{1}{c}{$\mathbf{2 0 1 5}$} & \multicolumn{1}{c}{$\mathbf{2 0 1 6}$} & \multicolumn{1}{c}{$\mathbf{2 0 1 7}$} \\
\hline Januari & 528506 & 597558 & 658308 \\
Pebruari & 483221 & 513852 & 520462 \\
Maret & 503311 & 576438 & 618834 \\
April & 528668 & 534395 & 705710 \\
Mei & 651089 & 647790 & 646467 \\
Juni & 571646 & 1035563 & 659718 \\
Juli & 799765 & 1084950 & 890368 \\
Agustus & 641684 & 704662 & 790323 \\
September & 557081 & 725240 & 832026 \\
Oktober & 619599 & 685244 & 732720 \\
Nopember & 529381 & 655962 & 741649 \\
Desember & 733149 & 882026 & 939048 \\
BALI & $\mathbf{7 1 4 7 ~ 1 0 0}$ & $\mathbf{8 6 4 3 6 8 0}$ & $\mathbf{8 7 3 5 6 3 3}$ \\
Pertumbuhan & & $\mathbf{2 0 , 9 4}$ & $\mathbf{1 , 0 6}$ \\
\hline Sumber: BPS Propi
\end{tabular}

Sumber: BPS Propinsi Bali, 2017

Meningkatnya jumlah wisatawan yang berkunjung juga berdampak pada meningkatnya jumlah hunian kamar pada hotel bintang tiga di Bali. Badan Pusat Statistik Provinsi Bali menunjukkan bahwa jumlah hotel berbintang di Bali pada tahun 2017 berjumlah 551 hotel, meningkat dua kali lipat dibanding tahun 2015 yang berjumlah 281 hotel. Selanjutnya Kepala Bidang Statistik Distribusi Badan Pusat Statistik (BPS) Provinsi Bali, I Nyoman Gede Subadri mengatakan tingkat penghunian hotel (TPK) berbintang di daerah tujuan wisata Pulau Bali mencapai $67,55 \%$ pada bulan Mei 2018, atau naik 4,02\% dibandingkan dengan bulan sebelumnya ( $\mathrm{m}$ to-m) yang tercatat $63,53 \%$. Hotel berbintang tiga dengan hunian 66,69\% pada bulan Mei 2018 meningkat $7,3 \%$ dari bulan sebelumnya hanya $59,39 \%$. Sementara itu, hotel berbintang lima dengan tingkat hunian mencapai 64,75\% pada bulan Mei 2018, meningkat tipis $1,08 \%$ dari bulan sebelumnya tercatat $63,67 \%$ dan hotel berbintang satu dengan hunian 52,08\%, meningkat 6,37\% dari bulan April 2018 tercatat 45,71\% (Oklelifestyle, 2018).

Data-data di atas menunjukkan preferensi turis lokal untuk menjadikan Bali sebagai tempat destinasi liburan tinggi dan dibuktikan dengan peningkatan jumlah turis lokal dari tahun 2015-2017 dan tingkat penghunian hotel berbintang terutama hotel bintang tiga di Bali di tahun 2018. Hal ini mendorong para pihak yang bergelut dalam bisnis hotel di Bali untuk menjadi lebih kreatif, aktif dan efektif dalam menarik konsumen dengan terus membentuk dan meningkatkan nilai citra merek hotel. Kotler and Keller (2012) menyatakan untuk mempermudah proses identifikasi suatu barang atau jasa, sebuah bisnis atau usaha membutuhkan brand atau merek. Dalam Patty (2015), brand image merupakan persepsi konsumen terhadap brand tertentu yang didasarkan atas pertimbangan dan perbandingan dengan brand lainya pada jenis produk yang sama.

Minat beli menurut Schiffman \& Kanuk (1997, p.131) adalah aktivitas psikis yang timbul karena adanya perasaan dan pikiran terhadap suatu barang dan jasa yang diinginkan. Konsumen akan melakukan suatu perilaku tertentu dengan cara tertentu berkaitan dengan kemampuan, penggunaan atau pemilihan produk atau jasa sehingga bisa jadi konsumen membentuk niat untuk mencari informasi, mengabarkan pada teman, kerabat, dan pihak lain tentang pengalamannya menggunakan produk tersebut, membeli produk, serta memilih untuk menggunakannya (Mowen \& Minor, 2002, p.322).

Melalui survei pendahuluan yang melibatkan 6 orang informan, ditemukan bahwa semua informan lebih cendrung mencari informasi mengenai hotel bintang tiga dengan bantuan review dari OTA dan menggunakan OTA untuk memilih akomodasi/ penginapan daripada agen perjalanan konvensional. Hasil dari survei pendahuluan ini menjadi alasan bagi peneliti untuk menggunakan hotel bintang tiga sebagai objek penelitian.

Selain itu, penelitian yang berjudul "The effect of Electronic Word of Mouth on Brand Image and Purchase Intention: An Empirical Study in the Automobile Industry in Iran" oleh Jalilvand \& Siamiei (2012) menunjukkan hasil yang menyatakan bahwa e-WOM adalah salah satu faktor yang efektif dalam mempengaruhi brand image dan purchase intention. Variabel yang sama juga dilakukan dalam penelitian ini. Hanya objek penelitian yang berbeda. Penelitian terdahulu melakukan studi pada Automobile Industry di Iran, sedangkan penelitian ini pada hotel bintang tiga di Bali, Indonesia. Sehingga judul penelitian ini adalah "Analisa Pengaruh e-WOM Terhadap Brand Image dan Purchase Intention pada Hotel Bintang Tiga di Bali". Adapun tujuan penelitian ini adalah untuk menjawab apakah e-WOM yang terdapat pada OTA berpengaruh terhadap brand image?, apakah brand image berpengaruh terhadap purchase intention?, dan apakah e-WOM yang terdapat pada OTA berpengaruh terhadap purchase intention pada hotel bintang tiga di Bali, Indonesia?

\section{TINJAUAN PUSTAKA}

\section{Electronic Word of Mouth}

Electronic word of mouth atau e-WOM adalah sebuah pernyataan positif maupun negatif yang terbentuk dari adanya opini para konsumen, baik para calon maupun mantan konsumen dari sebuah produk 
yang dapat diakses oleh khalayak luas melalui media internet (Hennig-Thurau, Gwinner, Walsh, Gremler, 2004). Konsumen dapat memposting pendapat, berkomentar dan memberi ulasan pada blog, forum diskusi, situs review, situs ritel, newsgroup dan media sosial atau jejaring sosial (Cheung \& Lee, 2012).

\section{Dimensi Electronic Word of Mouth}

Dalam Lin, Wu \& Chen (2013) terdapat 4 faktor utama dalam mengukur e-WOM yaitu e-WOM quality, e-WOM quantity, sender's expertise dan product involvement. Berhubung penelitian ini mengenai jasa maka penulis memutuskan untuk tidak menggunakan faktor yang terakhir product involvement dalam penelitian ini. Sehingga total dimensi e-WOM yang digunakan menjadi 3 dimensi berdarakan penelitian Lin, Wu \& Chen (2013), yaitu:

1. e-WOM quality, ditujukan untuk mendefenisikan kualitas isi dari review yang dibaca oleh konsumen dan mudah untuk dimengerti.

2. e-WOM quantity, mengacu pada jumlah komentar yang diposting dan dapat mewakili kinerja produk tersebut di mata konsumen. Banyaknya komentar juga mewakili popularitas atau kepentingan produk tersebut.

3. Sender's expertise, mengacu pada keahlian pengirim ketika membuat komentar untuk menarik konsumen dalam membuat keputusan untuk membeli.

\section{Brand Image}

Kotler dan Keller (2012) menerangkan bahwa brand adalah nama, istilah, tanda, simbol, rancangan, atau kombinasi dari hal-hal tersebut. Yang dimaksudkan untuk mengidentifikasi barang atau jasa dari seseorang atau sekelompok penjual dan untuk membedakannya dari produk pesaing. Juga menerangkan bahwa, branding sudah ada sejak lama untuk membedakan produk dari produsen satu dengan yang lainnya.

\section{Dimensi Brand image}

Menurut Keller (2013) citra merek dapat tercipta dan bermakna menurut 3 dimensi penting yaitu:

1. Strength (kekuatan), merupakan kekuatan merek yang bergantung pada bagaimana informasi dari produk tersebut masuk ke dalam ingatan konsumen dan bagaimana informasi tersebut dikelola sehingga dapat menjadi bagian dari brand image.

2. Uniqueness (keunikan), merupakan tingkat keunikan merek yang memiliki manfaat bersifat kompetitif dan sustainable yang menyebabkan konsumen tertarik untuk menggunakannya atau variasi layanan yang bisa diberikan sebuah produk baik variasi harga maupun diferensiasi dari penampilan fisik sebuah produk.

3. Favorability (kesukaan), merupakan keyakinan seorang konsumen bahwa produk tersebut mampu memuaskan keinginan konsumen sehingga dapat tercipta suatu sikap yang positif terhadap suatu merek. Keuntungannya adalah konsumen percaya bahwa atribut dan manfaat yang diberikan oleh suatu brand dapat memuaskan kebutuhan dan keinginan sehingga menciptakan sikap yang positif terhadap brand.

\section{Purchase Intention}

Purchase Intention menurut Schiffman \& Kanuk (1997, p.131) adalah indikator dari pendekatan konsumen terhadap pembelian dan aktivitas psikis yang timbul karena adanya perasaan dan pikiran terhadap suatu barang dan jasa yang diinginkan. Minat beli merupakan faktor yang sangat penting bagi konsumen dalam membuat keputusan ketika membeli produk apa pun (Fishbein \& Ajzen, 1975).

\section{Dimensi Purchase Intention}

Menurut Ferdinand (2002) yang digunakan dalam Memarzadeh, Blum dan Adams (2015), purchase intention dapat di identifikasi melalui aspekaspek sebagai berikut:

1. Minat transaksional, merupakan kecenderungan konsumen untuk membeli sesuatu. Hal ini didorong oleh hasrat untuk selalu membeli.

2. Minat referensial, merupakan kecenderungan konsumen untuk mereferensikan merek tertentu. Hal ini akan menentukan minat beli konsumen berdasarkan referensi yang ada.

3. Minat preferensial, merupakan gambaran konsumen yang telah mengutamakan merek untuk keperluan di masa yang akan datang.

4. Minat eksploratif, merupakan minat yang menggambarkan perilaku seseorang yang akan selalu mencari informasi mengenai produk yang diminatinya dan mencari informasi untuk mendukung sifat-sifat positif dari produk tersebut.

\section{Hubungan antara e-WOM dan Brand Image}

Hennig-Thurau, Gwinner, Walsh \& Gremler (2004) mendefinisikan e-WOM sebagai pernyataan positif atau negatif yang dibuat oleh calon pelanggan, saat ini berstatus pelanggan, atau mantan pelanggan tentang produk atau jasa suatu perusahaan yang tersedia bagi banyak orang dan lembaga melalui 
Internet. Beberapa penelitian menunjukkan bahwa eWOM memberikan pengaruh yang kuat dan positif terhadap brand image (Jalilvand \& Samiei, 2012); (Gozali \& Ruslim, 2012); (Kala \& Chaubey, 2018). Citra merek secara langsung akan dipengaruhi oleh persepsi konsumen tentang kualitas pelayanan dikarenakan citra mereka terbentuk dari pengalaman konsumsi dan kualitas layanan yang diterima konsumen (Aydin \& Ozer, 2005). Dari penjabaran di atas maka patut diduga bahwa:

H1: e-WOM pada OTA berpengaruh positif dan signifikan terhadap brand image pada hotel bintang tiga di Bali.

\section{Hubungan antara Brand Image dan Purchase Intention}

Kotler dan Keller (2012) menyatakan untuk mempermudah proses identifikasi suatu barang atau jasa, sebuah bisnis atau usaha membutuhkan brand atau merek. Konsumen mungkin mempunyai keinginan untuk membeli suatu produk berdasarkan merek yang paling diminati. Dalam penelitian sebelumnya yang dilakukan oleh (Torlak et.al, 2014); (Gozali dan Ruslim, 2015); (Jalilvand \& Samiei, 2012); (Kala dan Chaubey, 2018) mengatakan bahwa brand image akan berpengaruh positif dan signifikan pada keputusan membeli konsumen. Dari penjabaran di atas maka patut diduga bahwa:

$\mathrm{H} 2$ : Brand image berpengaruh positif dan signifikan terhadap purchase intention pada hotel bintang tiga di Bali.

\section{Hubungan antara e-WOM dan Purchase Inten- tion}

Lee, Park \& Han (2011) berpendapat bahwa kekuatan word of mouth lebih kuat daripada iklan konvensional khususnya dalam kemampuan untuk menciptakan sikap positif atau sikap negatif konsumen yang kemudian mempengaruhi sikap mereka dalam memilih suatu produk atau jasa. Schiffman \& Kanuk (1997) menjelaskan salah satu faktor yang dapat menimbulkan purchase intention konsumen adalah pengaruh eksternal. Pengaruh eksternal terdiri dari usaha pemasaran dan faktor sosial budaya. Faktor sosial budaya yang dimaksud adalah pengaruh yang berasal dari rekomendasi orang lain melalui word of mouth. Selain itu, beberapa peneliti (Chavalier \& Mayzlin, 2006); (Park, Lee \& Han, 2007); (Memarzadeh, Blum dan Adams, 2015) menyatakan dan menunjukkan adanya pengaruh yang positif dan signifikan dari e-WOM terhadap purchase intention konsumen. Dari penjabaran di atas maka patut diduga bahwa:
H3: e-WOM pada OTA berpengaruh positif dan signifikan terhadap purchase intention pada hotel bintang tiga di Bali.

\section{Model Penelitian}

Purchase intention dapat terjadi karena pengaruh dari brand image. Brand image dapat terbentuk melalui e-WOM dan di sisi lain e-WOM juga dapat berpengaruh langsung terhadap purchase intention. Adanya pengaruh langsung atau tidak langsung dari e-WOM terhadap purchase intention akan menentukan pentingnya peran brand image sebagai variabel mediasi.

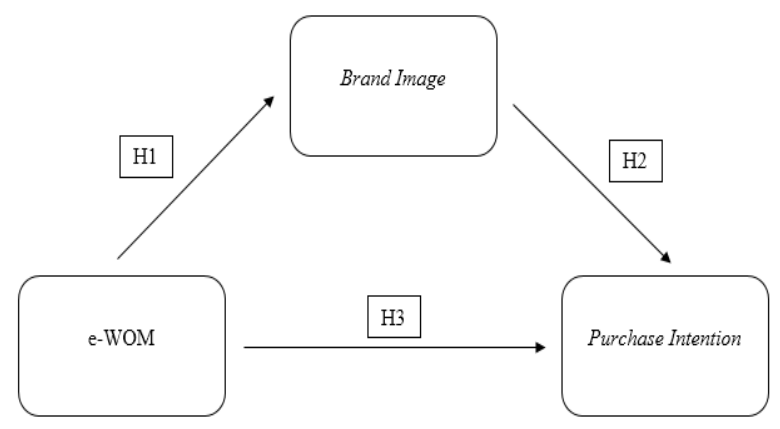

Gambar 1. Model Penelitian

\section{METODE PENELITIAN}

Jenis penelitian ini adalah penelitian asosiatif yang bertujuan untuk mengetahui pengaruh antara dua variabel atau lebih (Siregar, 2013). Populasi yang digunakan sebagai objek penelitian adalah turis lokal Indonesia yang pernah membaca review dalam OTA mengenai hotel bintang tiga yang berlokasi di Bali. Metode pengambilan sampel menggunakan metode purposive sampling. Dalam Sugiyono (2012), metode purposive sampling adalah metode penetapan responden untuk dijadikan sampel berdasarkan pada kriteriakriteria tertentu. Kriteria tersebut adalah responden minimal berumur 18 tahun dan pernah membaca review dari OTA mengenai hotel bintang tiga yang berlokasi di Bali.

Jenis dan sumber data dari penelitian ini adalah kuantitatif dengan menggunakan data primer. Data primer diperoleh melalui survey dengan cara menyebarkan kuesioner secara online dan offline. Kuisioner online disebarkan melalui link link google form di media sosial seperti Line dan Whatsapp pada tanggal 5-7 Januari 2019. Sedangkan kuesioner offline disebarkan di foodwave mall ciputra world surabaya. Dengan cara peneliti terjun langsung ke lapangan dan meminta kesediaan responden yang sesuai dengan kriteria sampel penelitian untuk mengisi kuesioner dalam google form. 
Jumlah minimal responden yang dipakai dalam penelitian ini menggunakan rumus Lemeshow (Lemeshow, Hosmer, Klar \& Lwanga, 1990) dikarenakan jumlah populasi yang tidak dapat diketahui jumlahnya dengan pasti. Rumus Lemeshow adalah sebagai berikut:

$$
n=\frac{p q}{\left(\frac{E}{1,96}\right)^{2}}
$$

Keterangan: $\mathrm{n}=$ jumlah sampel, $\mathrm{p}=$ Estimasi proporsi $(50 \%), \mathrm{q}=1-\mathrm{p}, \mathrm{E}=$ Alpha atau besarnya toleransi kesalahan (5\%), sehingga;

$$
n=\frac{0.5(1-0.5)}{\left(\frac{0.05}{1.96}\right)^{2}}=192,08
$$

Maka berdasarkan pertimbangan dan rumus yang digunakan, jumlah sampel yang dipakai adalah minimal 193 responden. Peneliti berhasil mengumpulkan 221 data tetapi peneliti hanya menggunakan 213 data karena 8 data yang lain tidak valid. Delapan (8) data dikategorikan tidak valid karena responden belum pernah membaca review mengenai hotel bintang tiga yang di Bali melalui OTA.

\section{Definisi Operasional Variabel (DOV)}

Definisi operasional variabel atau DOV adalah bentuk operasional dari variabel-variabel yang akan digunakan di dalam penelitian. Dalam Siregar (2013) mengatakan bahwa DOV berisi definisi konseptual dan indikator yang digunakan. Berikut adalah DOV dari penelitian ini:

\section{a. Variabel Independen}

Variabel e-WOM sendiri merupakan sebuah pernyataan positif maupun negatif yang terbentuk dari adanya opini para konsumen, baik para calon maupun mantan konsumen dari sebuah produk yang dapat diakses oleh khalayak luas melalui media internet (Hennig-Thurau, Gwinner, Walsh, Gremler, 2004). Dalam Lin, Wu dan Chen (2013) e-WOM memiliki indikator empiris yang akan digunakan dalam mengukur indikator $e W O M$ dalam penelitian ini, yaitu:

1. e-WOM Quality

Berbicara tentang isi review yang dapat dipahami oleh konsumen, meliputi:

e-WOM 1: Menurut pembaca review, isi review mengenai hotel bintang tiga di Bali dalam OTA jelas.

e-WOM 2: Menurut pembaca review, review dalam OTA mengenai hotel bintang tiga di Bali mudah dipahami.

e-WOM 3: Menurut pembaca review, isi review dalam OTA mengenai hotel bintang tiga di Bali dapat dipercaya.
e-WOM 4: Menurut pembaca review, isi review dalam OTA mengenai hotel bintang tiga di Bali konsisten.

\section{2. e-WOM Quantity}

Berbicara mengenai jumlah komentar yang diposting dan dapat mewakili kinerja produk tersebut di mata konsumen, meliputi:

e-WOM 5: Menurut pembaca review, banyaknya jumlah review dalam OTA menandakan bahwa hotel bintang tiga di Bali sudah dikenal masyarakat.

e-WOM 6: Menurut pembaca review, banyaknya jumlah review dalam OTA menandakan bahwa hotel bintang tiga di Bali memiliki tingkat hunian tinggi.

e-WOM 7: Menurut pembaca review, banyaknya jumlah rekomendasi dalam OTA menunjukan hotel bintang tiga di Bali memiliki reputasi yang baik.

3. sender's expertise

sender's expertise mengacu pada keahlian pengirim ketika mereka membuat komentar untuk menarik konsumen dalam membuat keputusan untuk membeli.

e-WOM 8: Menurut pembaca review, penulis review dalam OTA menulis berdasarkan pengalaman pribadi saat menginap di hotel bintang tiga di Bali.

e-WOM 9: Menurut pembaca review, penulis review dalam OTA menyebutkan halhal baru yang belum terpikirkan oleh saya mengenai hotel bintang tiga di Bali.

\section{b. Variabel Mediasi}

Variabel mediasi dalam penelitian ini adalah brand image. Brand image merupakan seperangkat keyakinan, ide, dan kesan yang dimiliki seseorang terhadap hotel bintang tiga di Bali. Definisi operasional dari brand image adalah sebuah penentu/pendukung e-WOM yang didasari oleh sebuah brand image yang sudah ada dalam pemikiran konsumen tentang sebuah merek yang telah diasosiasikan menjadi sebuah makna (Keller, 2013). Variabel brand image memiliki beberapa sub-variabel, yaitu:

1. Uniqueness of Brand (keunikan merek)

BI 1: Setelah membaca review dalam OTA, pembaca review beranggapan bahwa hotel bintang tiga di Bali memiliki nama hotel yang unik.

BI 2: Setelah membaca review dalam OTA, pembaca review beranggapan bahwa hotel bintang tiga di Bali merupakan hotel dengan desain dan fasilitas yang menarik. 
2. Strength of Brand (kekuatan merek)

BI 3: Setelah membaca review dalam OTA, pembaca review beranggapan bahwa hotel bintang tiga di Bali memiliki nama yang terkenal.

BI 4: Setelah membaca review dalam OTA, pembaca review beranggapan bahwa hotel bintang tiga di Bali merupakan hotel dengan image yang baik.

BI 5: Setelah membaca review dalam OTA, pembaca review beranggapan bahwa hotel bintang tiga di Bali merupakan hotel dengan lokasi yang strategis.

BI 6: Setelah membaca review dalam OTA, pembaca review beranggapan bahwa hotel bintang tiga di Bali merupakan hotel dengan staf yang kompeten.

BI 7: Setelah membaca review dalam OTA, pembaca review beranggapan bahwa hotel bintang tiga di Bali merupakan hotel dengan tingkat hunian yang tinggi.

3. Favorability of Brand (kesukaan)

BI 8: Setelah membaca review dalam OTA, pembaca review beranggapan bahwa hotel bintang di Bali memiliki value for money (sebanding dengan uang yang dikeluarkan) yang baik.

BI 9: Setelah membaca review dalam OTA, pembaca review beranggapan bahwa hotel bintang tiga di Bali memiliki kesan nyaman untuk ditempati.

BI 10: Setelah membaca review dalam OTA, pembaca review beranggapan bahwa hotel bintang tiga di Bali merupakan hotel yang aman.

BI 11: Setelah membaca review dalam OTA, pembaca review beranggapan bahwa hotel bintang tiga di Bali merupakan hotel dengan kamar yang bersih.

\section{c. Variabel Dependen}

Variabel dependen dalam penelitian ini adalah purchase intention. Purchase intention atau minat beli merupakan keinginan yang muncul dalam diri konsumen terhadap suatu hotel sebagai dampak dari suatu proses pengamatan dan pembelajaran dari informasi-informasi yang dikumpulkan dari OTA yang memberikan review dalam akomodasi hotel bintang tiga di Bali. Berikut merupakan indikatorindikator purchase intention yang digunakan dalam penelitian ini:

PI 1: Setelah membaca review dalam OTA, pembaca review memiliki keinginan untuk melakukan reservasi pada hotel bintang tiga di Bali
PI 2: Pembaca review akan menggunakan review dalam OTA sebagai sumber utama saya dalam melakukan reservasi di hotel bintang tiga di Bali.

PI 3: Pembaca review akan merekomendasikan teman saya untuk membaca review dalam OTA sebelum melakukan reservasi pada hotel bintang tiga di Bali.

PI 4: Pembaca review akan membaca review dalam OTA mengenai hotel bintang tiga di Bali sebelum melakukan reservasi di waktu yang akan datang.

\section{HASIL PENELITIAN DAN PEMBAHASAN}

\section{Profil Responden}

Dari jumlah responden sebanyak 213 responden, berdasarkan jenis kelamin hampir seimbang dimana wanita sebesar $52 \%$ dan pria sebesar $48 \%$. Untuk usia responden, usia 18-25 tahun memiliki presentase terbanyak dengan jumlah $70 \%$. Untuk aplikasi OTA responden lebih banyak mengenal dan menggunakan Traveloka sebesar $42 \%$. Tempat tinggal responden terbanyak berada di Surabaya sebesar 67\%. Dan ratarata responden lebih menggenal Ibis Style sebesar $19 \%$ dibandingkan dengan hotel bintang tiga lainnya.

Tabel 2. Profil Responden

\begin{tabular}{|c|c|c|}
\hline Kategori & Jumlah & Presentase \\
\hline \multicolumn{3}{|l|}{ Jenis Kelamin } \\
\hline Pria & 102 & $48 \%$ \\
\hline Wanita & 111 & $52 \%$ \\
\hline \multicolumn{3}{|l|}{ Usia } \\
\hline $18-25$ Tahun & 150 & $70 \%$ \\
\hline $26-30$ Tahun & 35 & $16 \%$ \\
\hline $31-35$ Tahun & 14 & $7 \%$ \\
\hline$>35$ Tahun & 14 & $7 \%$ \\
\hline \multicolumn{3}{|c|}{ Aplikasi OTA yang Digunakan } \\
\hline Traveloka & 170 & $42 \%$ \\
\hline Tiket.com & 101 & $25 \%$ \\
\hline NusaTrip & 36 & $9 \%$ \\
\hline Pegipegi.com & 48 & $12 \%$ \\
\hline Rajakamar.com & 32 & $8 \%$ \\
\hline Lainnya & 20 & $4 \%$ \\
\hline \multicolumn{3}{|l|}{ Tempat Tinggal } \\
\hline Surabaya & 142 & $67 \%$ \\
\hline Jakarta & 33 & $16 \%$ \\
\hline Bali & 6 & $2 \%$ \\
\hline Lainnya & 32 & $15 \%$ \\
\hline \multicolumn{3}{|l|}{ Hotel Bintang Tiga } \\
\hline Amaris Hotel & 91 & $13 \%$ \\
\hline Best Western Kuta & 104 & $16 \%$ \\
\hline Maxone Hotel & 69 & $10 \%$ \\
\hline Ibis Style & 130 & $19 \%$ \\
\hline Swiss-Belinn Legian & 94 & $14 \%$ \\
\hline Core Hotel Benoa & 40 & $5 \%$ \\
\hline The Alea Hotel Seminyak & 75 & $11 \%$ \\
\hline Santika Nusa Dua & 88 & $12 \%$ \\
\hline Lainnya & 0 & $0 \%$ \\
\hline
\end{tabular}




\section{Deskripsi Indikator Dan Variabel Penelitian}

Skor nilai tertinggi jawaban responden adalah 5 dan nilai terendah yaitu 1 . Dengan demikian nilai skor interval pada nilai rata-rata jawaban responden adalah 0.8 , sehingga pengkatagorian rata-rata jawaban seperti pada tabel 3 .

Tabel 3. Kategori Rata-Rata dari Skor Interval

\begin{tabular}{ll}
\hline Interval & Keterangan \\
\hline $1-1.8$ & Sangat Tidak Setuju \\
$1.81-2.6$ & Tidak Setuju \\
$2.61-3.40$ & Netral \\
$3.41-4.20$ & Setuju \\
$4.21-5.00$ & Sangat Setuju \\
\hline
\end{tabular}

Berikut ini merupakan hasil perhitungan mean dari variabel e-WOM, brand image dan purchase intention yang dapat dilihat pada Tabel 4, Tabel 5 dan Tabel 6.

Tabel 4. Mean Variabel e-WOM

\begin{tabular}{ccc}
\hline Variabel e-WOM & Mean & Kategori \\
\hline Indikator e-WOM 1 & 4,09 & Setuju \\
Indikator e-WOM 2 & 4,33 & Sangat setuju \\
Indikator e-WOM 3 & 4,05 & Setuju \\
Indikator e-WOM 4 & 4,08 & Setuju \\
Indikator e-WOM 5 & 4,31 & Sangat setuju \\
Indikator e-WOM 6 & 4,43 & Sangat setuju \\
Indikator e-WOM 7 & 4,30 & Sangat setuju \\
Indikator e-WOM 8 & 4,46 & Sangat setuju \\
Indikator e-WOM 9 & 3,99 & Setuju \\
\hline Rata-rata & 4,22 & Sangat setuju \\
\hline
\end{tabular}

Pada tabel 4, nilai rata-rata variabel e-WOM sebesar 4.22, nilai ini di atas 4,2 menunjukkan bahwa e-WOM dinilai sangat setuju oleh pelanggan Hotel Bintang 3 di Bali. Indikator e-WOM 8 paling tinggi dengan nilai mean 4,46 menunjukan sangat setuju di mata pelanggan, sedangkan yang paling rendah terdapat pada indikator e-WOM 9 dengan mean sebesar 3,99.

Tabel 5. Mean Variabel Brand Image

\begin{tabular}{lcc}
\hline Variabel Brand Image & Mean & Kategori \\
\hline Indikator BI1 & 3,97 & Setuju \\
Indikator BI 2 & 4,08 & Setuju \\
Indikator BI 3 & 4,20 & Setuju \\
Indikator BI 4 & 4,15 & Setuju \\
Indikator BI 5 & 4,40 & Sangat setuju \\
Indikator BI 6 & 4,10 & Setuju \\
Indikator BI 7 & 4,42 & Sangat setuju \\
Indikator BI 8 & 4,29 & Sangat setuju \\
Indikator BI 9 & 4,36 & Sangat setuju \\
Indikator BI 10 & 4,38 & Sangat setuju \\
Indikator BI 11 & 4,23 & Sangat setuju \\
\hline \multicolumn{1}{c}{ Rata-rata } & 4,23 & Sangat setuju \\
\hline
\end{tabular}

Nilai rata-rata variabel brand image sebesar 4.23 (Tabel 5), nilai ini di atas 4,2 menunjukkan bahwa brand image dinilai sangat setuju oleh pelanggan Hotel Bintang 3 di Bali. Indikator brand image 7 (BI 7) paling tinggi dengan nilai mean 4,42 menunjukan sangat setuju di mata pelanggan, sedangkan yang paling rendah terdapat pada indikator brand image 1 (BI 1) dengan mean sebesar 3,97 menunjukan setuju.

Tabel 6. Mean Variabel Purchase Intention

\begin{tabular}{lcl}
\hline Purchase Intention & Mean & Kategori \\
\hline Indikator PI 1 & 4,22 & Sangat setuju \\
Indikator PI 2 & 4,41 & Sangat setuju \\
Indikator PI 3 & 4,44 & Sangat setuju \\
Indikator PI 4 & 4,51 & Sangat setuju \\
\hline \multicolumn{1}{c}{ Rata-rata } & 4,39 & Sangat setuju \\
\hline
\end{tabular}

Pada tabel 6, nilai rata-rata variabel purchase intention sebesar 4.39, nilai ini di atas 4,2 menunjukkan bahwa purchase intention dinilai sangat setuju oleh pelanggan Hotel Bintang 3 di Bali. Seluruh indikator purchase intention (PI 1 sampai PI 4) memiliki nilai rata-rata di atas 4,2 menunjukkan bahwa semua indikator sangat setuju di mata pelanggan.

\section{Analisa Partial Least Square}

Pada hasil analisa outer loading pertama, peneliti menemukan beberapa indikator yang harus dibuang karena berada dibawah nilai yang ditetapkan. Beberapa indikator tersebut antara lain, yaitu: eWOM 3, e-WOM 8, e-WOM 9, BI 7 dan BI 8. Kemudian dilakukan lagi pengukuran outer loading kedua. Berikut adalah tabel pengukuran outer loading kedua.

Tabel 7. Outer Loading Factor

\begin{tabular}{lccc}
\hline & BI & eWOM & PI \\
\hline BI1 & 0,683588 & & \\
BI10 & 0,58243 & & \\
BI11 & 0,689736 & & \\
BI2 & 0,748824 & & \\
BI3 & 0,600184 & & \\
BI4 & 0,630643 & & \\
BI5 & 0,521633 & & 0,708557 \\
BI6 & 0,519687 & & 0,694894 \\
BI9 & 0,532788 & & 0,544793 \\
PI1 & & & 0,622992 \\
PI2 & & & \\
PI3 & & & \\
PI4 & & 0,633258 & \\
eWOM1 & & 0,691447 & \\
eWOM2 & & 0,558699 & \\
eWOM4 & & 0,671699 & \\
eWOM5 & & 0,621943 & \\
eWOM6 & & 0,559358 & \\
eWOM7 & & & \\
\hline
\end{tabular}


Dapat dilihat dari tabel 7 nilai outer loading untuk masing-masing variabel sudah memenuhi ketentuan dan dapat digunakan untuk analisa selanjutnya.

\section{Analisa Koefisien Validitas Diskriminan dan Reliabilitas}

Tabel 8. Akar AVE dan Composite Reliability

\begin{tabular}{ccccc}
\hline Indikator & \multirow{2}{*}{ AVE } & $\begin{array}{c}\text { Akar } \\
\text { AVE }\end{array}$ & $\begin{array}{c}\text { Composite } \\
\text { reliability }\end{array}$ & $\begin{array}{c}\text { Cronbach's } \\
\text { Alpha }\end{array}$ \\
\hline e-WOM & 0,390901 & 0,625220 & 0,792 & 0,686 \\
$\begin{array}{c}\text { Brand } \\
\text { image }\end{array}$ & 0,380217 & 0,616617 & 0,844 & 0,798 \\
$\begin{array}{c}\text { Purchase } \\
\text { intention }\end{array}$ & 0,432587 & 0,657713 & 0,751 & 0,568 \\
\hline
\end{tabular}

Berdasarkan table 8, dapat dilihat bahwa nilai dari ketiga variabel sudah memenuhi kriteria cross loading dan nilai akar AVE, maka ke-tiga variabel sudah memenuhi syarat validitas diskriminan dan dapat dikatakan valid.

\section{Nilai R-Square}

Tabel 8a. Nilai R-square

\begin{tabular}{lc}
\hline \multicolumn{1}{c}{ Variabel } & R-square \\
\hline Electronic Word of Mouth & - \\
Brand image & 0,120439 \\
Purchase intention & 0,204754 \\
\hline
\end{tabular}

Dari tabel 8a, nilai $\mathrm{R}$-square untuk variabel Brand image memiliki arti bahwa presentase besarnya Brand image memiliki pengaruh sebesar $12 \%$. Sedangkan untuk variabel Purchase intention memiliki arti bahwa Purchase intention memiliki pengaruh sebesar 20\%

\section{Path Coefficient}

Tabel 9. Path Coefficient

\begin{tabular}{cccccc}
\hline & $\begin{array}{c}\text { Original } \\
\text { Sample } \\
(\mathbf{O})\end{array}$ & $\begin{array}{c}\text { Sample } \\
\text { Mean } \\
(\mathbf{M})\end{array}$ & $\begin{array}{c}\text { Standard } \\
\text { Deviation } \\
(\text { STDEV) }\end{array}$ & $\begin{array}{c}\text { Standard } \\
\text { Error } \\
(\text { STERR) }\end{array}$ & $\begin{array}{c}\text { T Statistics } \\
(\text { (O/STERR) }\end{array}$ \\
\hline BI $\rightarrow$ PI & 0,114586 & 0,146714 & 0,168410 & 0,168410 & 0,680396 \\
\hline eWOM $\rightarrow$ BI & 0,347044 & 0,396745 & 0,101600 & 0,101600 & 3,415767 \\
\hline eWOM $\rightarrow$ PI & 0,399786 & 0,408843 & 0,132803 & 0,132803 & 3,010369 \\
\hline
\end{tabular}

Berdasarkan nilai koefisien dan nilai T-statistic di atas, maka hasil uji untuk masing-masing hipotesis adalah sebagai berikut:

H1: e-WOM memiliki pengaruh yang positif dan signifikan terhadap brand image

$\mathrm{H} 2$ : brand image memiliki pengaruh yang positif namun tidak signifikan terhadap purchase intention
H3: e-WOM memiliki pengaruh yang positif dan signifikan terhadap purchase intention

Dari tabel 9 dapat dilihat bahwa nilai t-hitung dari hubungan antara e-WOM terhadap brand image dan e-WOM terhadap purchase intention memiliki nilai lebih besar dari 1,96 (t-tabel) sehingga hipotesis dapat diterima. Sedangkan untuk brand image terhadap purchase intention memiliki nilai t-hitung yang lebih kecil dari nilai t-tabel maka hipotesis ini tidak dapat diterima. Untuk nilai original sample ke-tiga variabel memiliki pengaruh yang positif.

\section{Pengaruh e-WOM terhadap Brand Image}

Hasil hipotesis pertama ini terbukti bahwa eWOM memiliki pengaruh yang positif dan signifikan terhadap brand image. Hasil ini mengkonfirmasi penelitian Torlak et al. (2014) dan Kala \& Chaubey (2018) yang menyatakan bahwa e-WOM memiliki pengaruh yang positif dan signifikan terhadap brand image.

Berdasarkan hasil penelitian ini, indikator eWOM yang memiliki nilai loading factor tertinggi (lihat Tabel 7) adalah e-WOM-2 yaitu review dalam OTA mengenai hotel bintang tiga di Bali mudah dipahami. Dan indikator brand image yang memiliki nilai loading factor tertinggi (lihat Tabel 7) adalah BI2 yaitu setelah membaca review dalam OTA, responden beranggapan bahwa hotel bintang tiga di Bali merupakan hotel dengan desain dan fasilitas yang menarik. Artinya responden terbesar yang berusia 1825 tahun (atau sebesar 70\% responden) dan bertempat tinggal di kota Surabaya (atau sebesar 67\% responden) menilai bahwa review dari OTA mudah dipahami sehingga mampu memberi gambaran kepada responden bahwa hotel bintang tiga di Bali merupakan hotel dengan desain dan fasilitas yang menarik, dan aplikasi OTA terbesar yang digunakan adalah Traveloka sebesar $42 \%$.

\section{Pengaruh Brand Image terhadap Purchase Intention}

Hipotesis kedua penelitian ini adalah brand image berpengaruh positif dan signifikan terhadap purchase intention pada hotel bintang tiga di Bali. Namun, hal tersebut tidak terbukti karena nilai $\mathrm{t}$ hitung kedua variabel lebih kecil dari nilai t-tabel, ini menunjukkan bahwa pengaruh antara kedua variabel positif namun tidak signifikan sehingga pernyataan ditolak. Hasil penelitian ini bertolak belakang dengan penelitian-penelitian terdahulu seperti Torlak et.al. 
(2014); Gozali dan Ruslim (2015); Jalilvand \& Samiei (2012); Kala dan Chaubey (2018).

Berdasarkan data yang didapat, dari pengukuran loading factor kedua, indikator brand image tertinggi (lihat Tabel 7) adalah BI-2 yaitu setelah membaca review dalam OTA, responden beranggapan bahwa hotel bintang tiga di Bali merupakan hotel dengan desain dan fasilitas yang menarik. Sedangkan untuk indikator purchase intention nilai tertinggi (lihat Tabel 7) adalah PI-1 yaitu responden memiliki keinginan untuk melakukan reservasi pada hotel bintang tiga di Bali.

Berdasarkan hasil penelitian ini, desain dan fasilitas yang menarik merupakan hal yang paling mencerminkan brand image dari hotel bintang tiga di Bali. Namun, bila dilihat hasil nilai mean-nya menunjukkan bahwa review dalam OTA yang mengenai hotel bintang tiga di Bali memiliki nama hotel yang unik lebih rendah dibandingkan dengan indikator yang lain. Hal ini didukung pula dengan kegiatan observasi dari peneliti ketika menelusuri aplikasi OTA yang digunakan di Traveloka (OTA yang paling banyak digunakan oleh responden, sebanyak $42 \%$ ), tidak banyak jumlah reviewer yang menulis tentang keunikan nama hotel bintang tiga di Bali. Sebagian besar responden adalah anak muda yang tidak peduli dengan sebuah nama yang unik, yang penting bagi kalangan muda adalah fasilitas yang menarik, aman dan nyaman serta lokasi hotel yang strategis guna memenuhi kebutuhan konsumen saat penginapan.

\section{Pengaruh e-WOM terhadap Purchase Intention}

Hipotesis ke tiga penelitian ini adalah e-WOM pada OTA berpengaruh positif dan signifikan terhadap purchase intention pada hotel bintang tiga di Bali. Hasil ini mengkonfirmasi penelitian Memarzadeh, Blum dan Adams (2015); Chavalier \& Mayzlin (2006); Park, Lee \& Han (2007) yang menyatakan bahwa $e$-WOM memiliki pengaruh yang positif dan signifikan terhadap purchase intention.

Berdasarkan Hasil penelitian ini, indikator eWOM yang memiliki nilai loading factor tertinggi adalah review dalam OTA mengenai hotel bintang tiga di Bali mudah dipahami. Dan indikator purchase intention yang memiliki nilai loading factor tertinggi adalah setelah membaca review dalam OTA, responden memiliki keinginan untuk melakukan reservasi pada hotel bintang tiga di Bali. Artinya sebagian besar responden menilai bahwa setelah membaca review dalam OTA yang mudah dipahami menyebabkan responden memiliki keinginan untuk melakukan reservasi pada hotel bintang tiga di Bali.

\section{KESIMPULAN DAN SARAN}

Penelitian ini membuktikan bahwa terdapat pengaruh positif signifikan e-WOM melalui aplikasi online OTA terhadap brand image dan purchase intention, sedangkan brand image tidak berpengaruh terhadap purchase intention pada hotel bintang tiga di Bali. Implikasi dari temuan penelitian ini adalah pengelola hotel bintang tiga di Bali agar berupaya mendesain dan menyediakan fasilitas yang menarik, aman dan nyaman serta lokasi hotel yang strategis untuk konsumen dalam upaya membangun e-WOM melalui aplikasi online OTA terhadap brand image dan purchase intention. Bukti empiris ini membuka kesempatan pada konsumen untuk menceritakan kembali pada aplikasi online OTA, karena hasil temuan menunjukan bahwa konsumen yang membaca review dalam OTA mudah memahami dan menyebabkan konsumen memiliki keinginan untuk melakukan reservasi pada hotel bintang tiga di Bali. Bila dibandingkan dengan brand image tidak berpengaruh terhadap purchase intention pada hotel bintang tiga di Bali, maka pelaku hotel bintang tiga di Bali seharusnya tidak hanya bertumpu pada brand image dengan nama hotel yang unik saja, karena hal tersebut tidak memberi dampak pada konsumen untuk melakukan reservasi.

Bagi penelitian selanjutnya yang menggunakan $e-W O M$, brand image dan purchase intention sebagai variabel penelitian dapat dikembangkan lagi tidak hanya di dalam konteks hotel saja, tetapi dapat dikembangkan dalam bidang lain seperti dalam bidang pariwisata, restaurant dan produk-produk jasa lainnya yang memungkinkan untuk dilakukan penelitian yang sama seperti ini.

\section{DAFTAR REFERENSI}

Badan Pusat Statistik Provinsi Bali. (2018, July 10). Kunjungan Wisatawan Domestik ke Bali per Bulan, 2004-2017. Denpasar: BPS

Basri, N. H., Ahmad, R., Anuar, F. I., \& Ismail, K. A. (2016). Effect of Word of Mouth Communication on Consumer Purchase Decision: Malay upscale restaurant. Procedia-Social and Behavioral Sciences, $324-331$.

Chatterjee, P. (2001). Online reviews do consumers use them?. Journal Advances in Consumer Research, 28(4), 129-133.

DailySocialID. (2018, Oktober 4). Online Travel Agencies Survey 2018. Retrieved from Daily Socialid:https://dailysocial.id/report/post/onlinetravel-agencies-ota-survey-2018 
Ferdinand, A. (2002). Structural Equation Modelling. Management Research

Gilly, M., Celsi, M., Graham, J. L., Yale, L. J. (1998). A dyadic study of interpersonal information search. Journal of The Academy of Marketing, 26(2), 83-100.

Goyette, I., Ricard, L., Bergeron, J., \& Marticotte, F. (2010). e-WOM Scale: Word-of-Mouth Measurement Scale for e-Services Context. Canadian Journal of Administrative Sciences, 5-23.

Gozali, M. Y., \& Ruslim, T. S. (2012). Efek e-WOM Terhadap Brand Image dan Purchase Intention. Jakarta: Universitas Tarumanegara.

Henning-Thurau, T., Gwinner, K. P., Walsh, G., Gremler, D. D. (2004). Electronic word of mouth via consumer opinion platforms: What motivates consumers to atriculate themselves on the internet?. Journal of Interactive Marketing, 18(1), 38-52.

Jalilvand, M. R., \& Samiei, N. (2012). The Effect of Electronic Worf of Mouth on Brand Image and Purchase Intention. Marketing Intelligence \& Planning, 460-476.

Kala, D., \& Chaubey, D. S. (2018). Impact of Electronic Word of Mouth on Brand Image and Purchase Intention towards Lifestyle Products in India. Pacific Business Review International, 135-144.

Keller, K. L. (2013). Strategic brand Management: Building, Measuring and Managing Brand Equity (4 ed.). Pearson Education.

Kotler, P., \& Keller, K. L. (2012). Marketing management. New Jersey: Pearson Pretice Hall, Inc.

Lee, J., Park, D. H., Han, I. (2011). The different effects of online consumer reviews on consumers' purchase intentions depending on trust in online shopping malls: An advertising perspective. Internet Research, 21(2), 187-206.

Lin, C., Wu, Y.-S., \& Chen, J.-C. V. (2013). Electronic Word of Mouth: The Moderating Roles of Products Involvment and Brand Image. Technology Innovation and Industrial Managemen, $29-47$

Memarzadeh, F., Blum, S. C., \& Adams, C. (2015). The Impact of Positive and Negative ecomments on Business Travelers' Intention to Purchase a Hotel Room. Journal of Hospitality and Tourism Technology, 258-270.

Noor, J. (2014). Metodologi penelitian. Jakarta: Kencana Prenada Media Group.

Park, D. H., Lee, J. M., \& Han, I. G. (2007). The Effect of On-Line Consumer Reviews on Consumer Purchasing Intention. International Journal of Electronic Commerce, 125-148.

Schiffman, L. G., \& Kanuk, L. L. (1997). Perilaku konsumen. Edisi kelima, Prentice Hall.

Sekaran, U. (2006). Metodologi penelitian untuk bisnis. Edisi keempat, Jakarta: Salemba.

Siregar, S. (2013). Metode penelitian kuantitatif. Jakarta: PT. Fajar.

Sugiyono. (2012). Metode penelitian kuantitatif, kualitatif dan $R \& D$. Bandung: Alfabeta.

Torlak, O., Ozkara, B. Y., Tiltay, M. A., Cengiz, H., \& Dulger, M. F. (2014). The Effect of Electronic Word of Mouth on Brand Image and Purchase Intention: An Application Concerning Cell Phone Brands for Youth Consumers in Turkey. Journal of Marketing Development and Competitiveness, 61-68. 